\title{
Calcium/calmodulin-dependent protein kinase II
}

\author{
Roger J. COLBRAN, Charles M. SCHWORER, Yoshiaki HASHIMOTO, Y.-Lian FONG, Devra P. RICH, \\ M. Kevin SMITH and Thomas R. SODERLING* \\ Howard Hughes Medical Institute and Department of Molecular Physiology and Biophysics, Vanderbilt University School of \\ Medicine, Nashville, TN 37232, U.S.A.
}

\section{Introduction}

Transmembrane signalling by extracellular agonists is generally mediated by specific receptors and often results in alterations of the intracellular concentrations of either cyclic AMP, calcium, inositol polyphosphates or diacylglycerol. These intracellular regulatory molecules affect many physiological processes by mechanisms which often involve covalent phosphorylation of appropriate rate-limiting enzymes, ion channels or other proteins $[1,2]$. Three multifunctional protein kinases are thought to mediate many of these phosphorylation reactions, namely cyclic AMP-dependent protein kinase (cAMP-kinase), calcium/phospholipid-dependent protein kinase (protein kinase $C$ ) and calcium/calmodulin-dependent protein kinase II (CaM-kinase II).

CaM-kinase II is a member of a family of $\mathrm{Ca}^{2+} /$ calmodulin-regulated protein kinases which also includes $\mathrm{Ca}^{2+} /$ calmodulin-dependent protein kinases I and III, myosin light chain kinases and phosphorylase kinase $[3,4]$. Unlike the other members of this family, CaMkinase II can phosphorylate a large number of proteins, at least in vitro. For this reason CaM-kinase II was independently identified in the early 1980's by a number of laboratories studying diverse physiological processes such as neurotransmitter exocytosis [5], catecholamine biosynthesis [6], cytoskeletal interactions [7], and glycogen metabolism [8]. Although most investigators now use the terminology of calcium/calmodulindependent protein kinase II, the literature also refers to this kinase as calmodulin-dependent synapsin I kinase, calmodulin-dependent glycogen synthase kinase or the multifunctional calmodulin-dependent protein kinase. This review will attempt to summarize most of the features of CaM-kinase II, with particular emphasis on recent investigation of the structure/function properties of the kinase.

\section{Species, tissue and subcellular distribution}

CaM-kinase II is most highly concentrated in neural tissues, where it can represent as much as $2 \%$ of total protein in some regions (e.g. rat hippocampus) [9]. Thus the rat brain kinase is the best characterized. Studies from a number of laboratories have demonstrated that isoenzymes of CaM-kinase II are also present in most mammalian tissues examined. Indeed, the kinase has been highly purified from mammalian brain [7,10-14], liver $[8,15,16]$, skeletal muscle [17], heart [18], pancreas
[19], retina [20], lung [21], parathyroid [22], mammary gland [23] and intestinal brush border [24], as well as neural tissues of Aplysia [25], electric eel [26], squid [27] and Drosophila [28]. The isoenzymes are characterized by a large native molecular mass $(300-700 \mathrm{kDa})$, subunits in the range $50-62 \mathrm{kDa}$, and similar or identical catalytic properties against several protein substrates (references listed above and [29]). Peptide mapping studies of the separated subunits of ${ }^{125} \mathrm{I}$-labelled kinases from rat brain, rabbit liver and rabbit skeletal muscle indicate considerable structural homology, but with some differences [30]. The recent cloning of cDNAs to the subunits of the rat brain kinase has revealed that mRNAs with some homology to the brain cDNAs are present in skeletal muscle, intestine, liver, testis and pituitary [31-33], although the levels of expression are much lower than in brain. Calmodulin-dependent protein kinases have also been reported in yeast [34] and Aspergillus [35] which have some properties similar to CaM-kinase II, although the apparent native molecular mass of both kinases is much smaller. Further characterization is required to determine if they are truly isoenzymes of CaM-kinase II.

The subcellular distribution of CaM-kinase II varies depending on the tissue [36], presumably reflecting different physiological functions of the kinase and the presence of different isozymes. For example, most of the kinase activity is cytoplasmic in rat kidney (100\%), liver $(94 \%)$ and heart $(82 \%)$, whereas in cerebrum and testis most is particulate (88\% and $84 \%$, respectively) [36]. Immunological techniques have been used to demonstrate that in rat brain the subcellular distribution of the kinase, as well as its subunit composition, are under developmental control. The forebrain of 5-day postnatal rats contains approx. $80 \%$ cytoplasmic CaM-kinase II, with $\alpha(50 \mathrm{kDa})$ and $\beta(60 \mathrm{kDa})$ subunits in a molar ratio of about 1:4 [37]. Between days 5 and 20 there is a 10fold increase in CaM-kinase II, with $80 \%$ of the kinase now being particulate, and a 7:1 ratio of $\alpha$ and $\beta$ subunits [37]. The level of mRNA for the $\alpha$-subunit in forebrain also increases approx. 10-fold between postnatal days 1 and 21 [31]. In adult rat brain, the highest levels of CaMkinase II are found in the telencephalon regions (hippocampus, lateral septum, cortex, neostriatum, amygdaloid), with much lower activity in the cerebellum, diencephalon, mesencephalon, pons and medulla $[9,38]$. The ratio of subunits also varies between the different regions, with $\alpha$ and $\beta$ subunits present in a $4: 1$ ratio in rat forebrain and in a $1: 4$ ratio in cerebellum [12,39]. The variation in ratio of subunit polypeptides in these regions is paralleled by different ratios of the specific mRNA

\footnotetext{
Abbreviations used: CaM-kinase II, $\mathrm{Ca}^{2+} /$ calmodulin-dependent protein kinase II ; cAMP-kinase, cyclic AMP-dependent protein kinase; protein kinase $\mathrm{C}, \mathrm{Ca}^{2+} /$ phospholipid-dependent protein kinase.

* To whom correspondence and reprint requests should be addressed.
} 
species for each subunit [33]. Within the neuron, CaMkinase II appears to be distributed in the spines, somata, axons, dendrites and nerve terminal, with little in the nuclei [38]. In the dendrites of forebrain the kinase is particularly concentrated in the postsynaptic density, where the $\alpha$ subunit is the major postsynaptic density protein of $50 \mathrm{kDa}$, constituting $30-50 \%$ of the total protein [40-42].

\section{Subunit structure}

As noted above, CaM-kinase II is a heteropolymer comprised of subunits in the range 50-62 kDa depending on the tissue and species. Apparently all of the subunits contain both regulatory and catalytic functions. Initially, this conclusion was based on the observations that, following separation of the subunits by SDS/polyacrylamide-gel electrophoresis and renaturation, both the $\alpha$ and $\beta$ subunits of the rat brain kinase bind ${ }^{125} \mathrm{I}-$ labelled calmodulin $[7,11,12,14]$ and undergo autophosphorylation [43]. This conclusion has been confirmed by the recent publication of amino acid sequences for the $\alpha[31,32], \beta$ [44] and $\beta^{\prime}[33]$ subunits of the rat brain kinase deduced from cDNA clones. All the rat brain kinase subunits contain the consensus sequences for ATP binding, protein kinase catalytic activity and calmodulinbinding domains, as depicted schematically in Fig. 1. The sequences indicate that the $\alpha$ subunit contains 478 amino acids [32], and the $\beta$ and $\beta^{\prime}$ subunits have 542 [44] and 527 [33] amino acids, respectively, and are largely homologous. The $N$-terminal two-thirds (residues 1-315, $\beta$ ) of the subunits contain $91 \%$ identical amino acid sequences; the $C$-terminal region (residues 393-542, $\beta$ ) has $76 \%$ identical amino acid sequence; the central region (residues 316-392, $\beta$ ), which has the deletions (or insertions), shows much lower similarity [33].

The sequences (Fig. 1) indicate that the ATP-binding and catalytic properties of the kinase reside in the $N$-terminal portion, whereas the calmodulin-binding domain resides between residues 290 and 314 ( $\alpha$-subunit). The function of the $C$-terminal portion is not established, but it may be involved in the assembly of the kinase holoenzyme and/or in its subcellular localization. Evidence in favour of this conclusion comes from limited proteolysis of the isolated postsynaptic density, or the purified soluble kinase, with chymotrypsin, which releases an active $30 \mathrm{kDa}$ monomeric fragment of CaM-kinase II [45]. Treatment of autophosphorylated soluble brain kinase with trypsin or chymotrypsin also generates a $\mathrm{Ca}^{2+} /$ calmodulin-independent active species (32-34 kDa by SDS/polyacrylamide-gel electrophoresis), with loss of the initial autophosphorylation site (Thr-286) and calmodulin-binding domain (C. M. Schworer, unpublished work; see below). These results establish that most of the subunit degradation must occur in the $C$-terminal portion of the subunit.

\section{Substrates}

As stated in the Introduction, different protein substrates have been utilized by various investigators in the purification of CaM-kinase II. Several of these substrates have been characterized in substantial detail with regard to phosphorylation sites and the regulatory consequences of phosphorylation. Although many of the substrates for CaM-kinase II in vitro show increased phosphorylation in vivo in response to calcium-mobilizing agonists, the role of CaM-kinase II in vivo has only been studied in detail for a few substrates. Interestingly, it has recently been reported that sphingosine inhibits the activation of CaM-kinase II, and several other calmodulin-dependent enzymes, by $\mathrm{Ca}^{2+} /$ calmodulin, both in vitro and in vivo [168]. Since sphingosine was previously thought to be a specific inhibitor of protein

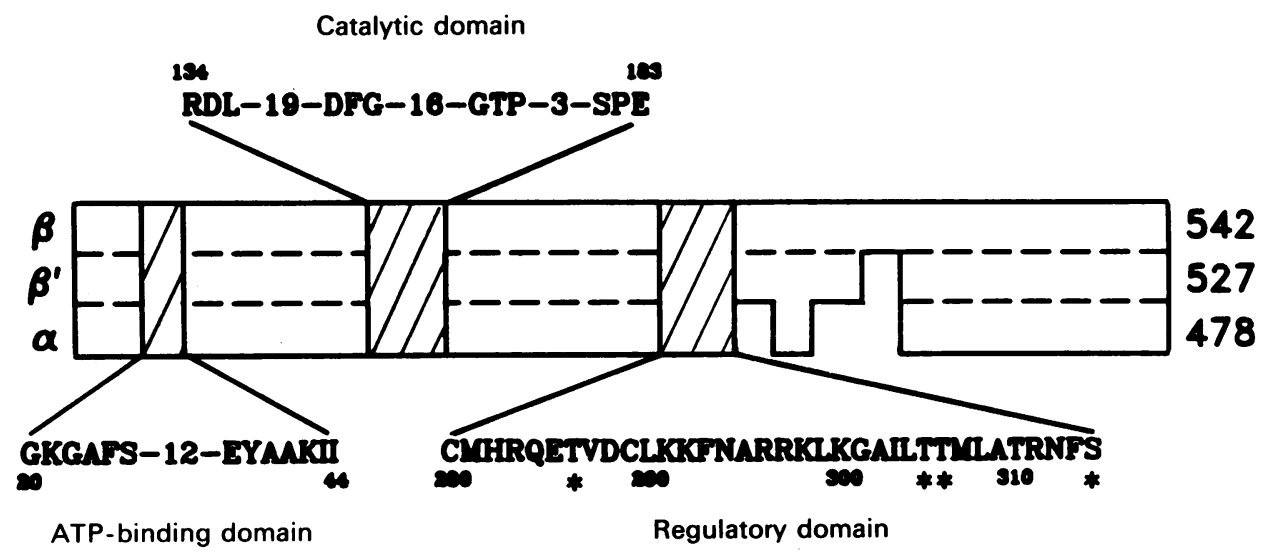

Fig. 1. Schematic representation and partial amino acid sequence of the subunits of rat brain CaM-kinase II

The linearized amino acid sequences of the $\alpha$ [31,32], $\beta^{\prime}$ [33] and $\beta$ [44] subunits of CaM-kinase II are represented by the open bar. Spaces in the $\alpha$ and $\beta^{\prime}$ subunits represent the position of deleted sequences relative to the $\beta$ subunit. The hatched areas with amino acid sequence are certain conserved regions between the subunits, with assigned functional roles based on data reviewed in the text and by alignment with other protein sequences. The numbers within the sequences denote the number of residues which have been omitted. The left and central hatched areas show homology with known protein kinase sequences [165] and represent putative ATP-binding and catalytic domains, respectively. The right hatched area represents the regulatory domain of the kinase and contains the calmodulin-binding (residues 296-309) and inhibitory (within residues 281-309) domains and several autophosphorylation sites (marked ${ }^{*}$ ). Details concerning these assignments can be found in the text. The numbering of amino acids is based on the $\alpha$ subunit sequence [32]. 
Table 1. Preferred phosphorylation sites for cyclic AMPdependent protein kinase and CaM-kinase II in glycogen synthase, phospholamban and tyrosine hydroxylase

The asterisk indicates the residue phosphorylated by each kinase and the underlined residues represent the arginine residues in the consensus phosphorylation sequence (see the text). The numbers under the sequence give the location of the phosphorylated residue in the amino acid sequence. The complete amino acid sequence of glycogen synthase has not been determined to date.

Preferred phosphorylation site

Protein CaM-kinase II cAMP-kinase Reference

\begin{tabular}{|c|c|c|c|}
\hline $\begin{array}{l}\text { Glycogen } \\
\text { synthase }\end{array}$ & $\begin{array}{l}\text {-R-T-L-S-V- } \\
\text { site } 2\end{array}$ & $\frac{-\mathrm{R}-\mathrm{R}-\mathrm{A}-\mathrm{*}-\mathrm{C}-}{\text { site la }}$ & {$[88,167]$} \\
\hline Phospholamban & $\begin{array}{c}-\mathrm{R}-\underline{\mathrm{R}}-\mathrm{A}-\mathrm{S}-{ }^{*}-\mathrm{I}-\mathrm{I} \\
8\end{array}$ & $\begin{array}{c}-\underline{R}-\mathrm{R}-\mathrm{A}-\stackrel{*}{\mathrm{~S}}-\mathrm{T}-\mathrm{I}- \\
7\end{array}$ & [103] \\
\hline $\begin{array}{l}\text { Tyrosine } \\
\text { hydroxylase }\end{array}$ & $\begin{array}{c}-\underline{\mathrm{R}}-\mathrm{A}-\mathrm{V}-\stackrel{*}{\mathrm{~S}}-\mathrm{E}- \\
19\end{array}$ & $\frac{-\mathrm{R}-\mathrm{R}-\mathrm{Q}-{ }^{*}-\mathrm{L}-}{40}$ & {$[76]$} \\
\hline
\end{tabular}

kinase $\mathrm{C}$, earlier studies investigating the role of protein kinase $C$ in vivo using sphingosine may need to be reevaluated for the possible involvement of CaM-kinase II or other calmodulin-dependent enzymes in these systems.

Substrate specificity determinants. The amino acid sequences surrounding phosphorylation sites of several substrates for CaM-kinase II have been determined. Examination of the available amino acid sequences reveals that an arginine three residues $N$-terminal of the phosphorylated serine or threonine is common to all the sequences, and is missing from sequences phosphorylated by other protein kinases, but not CaM-kinase II [16]. This comparison was most striking with the purified $20 \mathrm{kDa}$ myosin light chains from smooth, skeletal and cardiac muscle, which are all good substrates for myosin light chain kinase. The smooth muscle light chain is also a relatively good substrate for CaM-kinase II, whereas cardiac and skeletal muscle light chains are not phosphorylated [16]. Although there is great sequence homology around the phosphorylation site for myosin light chain kinase, only the smooth muscle light chain has an arginine three residues $N$-terminal of the serine.

Based on these observations, synthetic peptides modelled after the smooth muscle myosin light chain sequence were constructed [46]. A peptide with sequence K-K-A-P-Q-R-A-A-S-N-V-F-A-M is a good substrate for CaM-kinase II (apparent $K_{\mathrm{m}}=27 \mu \mathrm{M}, V_{\max .}=$ $1 \mu \mathrm{mol} / \mathrm{min}$ per $\mathrm{mg}$ ) from rabbit liver, but when the arginine residue is replaced with alanine the peptide is not significantly phosphorylated, confirming the essential nature of the arginine three residues $N$-terminal of the serine [46]. Interestingly, when a second arginine is added (-R-R-A-S-), there is a 10-fold decrease in the ratio $V_{\text {max }} / K_{\mathrm{m}}$. Thus, addition of the second arginine is a strong negative determinant for CaM-kinase II. This is of particular interest since addition of the second arginine is a strong positive determinant for cAMP-kinase $[47,48]$.
This pattern of site specificity appears to occur in intact proteins as evidenced by glycogen synthase, phospholamban and tyrosine hydroxylase (Table 1; see below), although it should be pointed out that the specificity is relative and there is some overlap between the two kinases (e.g. pyruvate kinase and phenylalanine hydroxylase; see below). In a more extensive study, Pearson et al. [49] synthesized synthetic peptides based on the amino acid sequence surrounding phosphorylation site 2 of glycogen synthase. In their study the effects of position, number and type of basic residues was investigated using rabbit skeletal muscle CaM-kinase II, and their data also support a minimum specificity determinant of -R-X-X-S/T- for CaM-kinase II. Interestingly, it was shown that lysine could not substitute effectively for arginine [49].

Brain synapsin. Synapsin I, a neuron-specific protein localized in the presynaptic terminals and associated with the outer surface of presynaptic vesicles [50,51], is a very good substrate for CaM-kinase II in vitro. Phosphorylation can attain a stoichiometry of approx. $1.8 \mathrm{~mol} / \mathrm{mol}$ in two sites (2 and 3 ) in the collagenasesensitive domain of synapsin I [52,53]. In contrast, cAMP-kinase [52] and $\mathrm{Ca}^{2+} /$ calmodulin-dependent protein kinase I [54] phosphorylate synapsin I at a distinct site (site 1). Analysis of the phosphorylation sites in bovine and rat synapsin [53] reveal that sites 2 and 3 conform to the consensus phosphorylation sequence for CaM-kinase II. Synapsin I is thought to play a critical role in the release of neurotransmitter at nerve synaptic vesicles and inhibits neurotransmitter exocytosis by interfering with vesicle movement or fusion with the plasma membrane. Following site-specific phosphorylation by CaM-kinase II, synapsin I is thought to dissociate from synaptic vesicles, thereby facilitating exocytosis. In support of this hypothesis, it has been shown that phosphorylation of site 2 in synapsin I by CaM-kinase II decreases its affinity for synaptic vesicles [55]. Also, in experiments using the squid giant synapse [56], microinjection of dephosphosynapsin I into the presynaptic terminal decreases the postsynaptic potential, presumably reflecting a decrease in neurotransmitter release, in response to a constant presynaptic depolarizing step. On the other hand, microinjection of CaM-kinse II resulted in increased postsynaptic potentials [56], presumably as a result of phosphorylation of a squid synapsin-like protein, dissociation of the phosphoprotein from synaptic vesicles, and thereby relief of inhibition of neurotransmitter release. CaM-kinase II is known to be highly localized in synaptosomes of squid [27]. Recent data $[57,58]$ suggest that dephosphosynapsin I promotes bundling of the actin filaments in which the synaptic vesicles are embedded. Phosphorylation of synapsin I at sites 2 and 3 by CaM-kinase II abolishes this actinbundling ability. Thus, synapsin I may provide a link between small synaptic vesicles and the actin-based cytoskeleton in a phosphorylation-dependent manner.

Brain microtubule-associated proteins: MAP-2 and $\tau$. Microtubules are known to consist of tubulin and several microtubule-associated proteins or MAPs, some of which have been studied extensively. One of these, MAP2 , contains about 22 phosphorylation sites, 13 that are cyclic AMP-dependent and at least 8 that are cyclic AMP-independent [59]. MAP-2 is readily phosphorylated 
by CaM-kinase II in vitro $[7,10,11,60]$, and peptide mapping techniques indicate that eight phosphorylation sites are involved [61,62]. Dephospho-MAP-2 is known to promote the assembly of microtubules, but phosphorylation by CaM-kinase II inhibits MAP-2-stimulated microtubule assembly [63]. CaM-kinase II is localized in microtubule preparations even after the extensive isolation procedure [64].

Another microtubule-associated protein, $\tau$ protein, is also phosphorylated in vitro by CaM-kinase II [65]. This phosphorylation has been described as a mode I phosphorylation that is characterized in part by the reduced mobility of $\tau$ protein in SDS/polyacrylamide gels [65]. $\tau$ protein is a poor substrate for cAMP-kinase in vitro, but is phosphorylated in mode II (mobility on SDS/polyacrylamide gels does not change) by protein kinase C [66]. Interestingly, the mobility shift induced by mode I phosphorylation resembles that which has been observed in $\tau$ protein purified from the paired helical filaments of degenerative neurons in Alzheimer's disease $[67,68]$. Like MAP- $2, \tau$ protein is also known to promote microtubule protein polymerization, and mode I phosphorylation of $\tau$ protein inhibits this stimulation of microtubule formation [69].

Brain tyrosine hydroxylase. Tyrosine hydroxylase, the rate-limiting enzyme in catecholamine biosynthesis, can be phosphorylated in vitro by cAMP-kinase [70-72], protein kinase C [73] and CaM kinase II $[6,74,75]$, as well as by some undefined kinases [76,77]. cAMP-kinase and protein kinase $C$ phosphorylate predominantly Ser- 40 in the pheochromocytoma tyrosine hydroxylase [76], resulting in enzyme activation due to a decrease in the $K_{\mathrm{m}}$ for its pterin cofactor [73,78]. CaM-kinase II phosphorylates tyrosine hydroxylase primarily at Ser-19 with slight phosphorylation at Ser-40 [76], with no significant direct effect on the $K_{\mathrm{m}}$ for either its pterin cofactor or the tyrosine substrate, or on the $V_{\max }$. $[75,79]$. However, Fujisawa and coworkers have purified a protein from brain that activates tyrosine hydroxylase only when it has previously been phosphorylated by CaM-kinase II [80], by a mechanism involving a 2-3-fold increase in $V_{\max }$. [79]. The activator protein has no effect on nonphosphorylated tyrosine hydroxylase, or on tyrosine hydroxylase phosphorylated by cAMP-kinase [79].

Treatment of brain slices [81], PC12 cells [82] or adrenal chromaffin cells [83] with depolarizing agents results in a calcium-dependent increase in tyrosine hydroxylase phosphorylation with a 2-3-fold increase in the $V_{\max }$ of tyrosine hydroxylase. However, in PC12 cells there is a temporal dissociation of these effects since phosphorylation of tyrosine hydroxylase reaches a maximum at approx. $1 \mathrm{~min}$ and is maintained for at least 5 min, whereas activation of the enzyme does not reach a maximum until approx. 3 min after stimulation [82]. In PC12 cells it has been demonstrated that the phosphorylation sites increased by a 5 min depolarization with 56 $\mathrm{mM}-\mathrm{KCl}$ correspond to the sites phosphorylated in vitro by CaM-kinase II [84]. A more detailed study using $\left[{ }^{32} \mathrm{P}\right] \mathrm{P}_{\mathrm{i}}$-labelled bovine adrenal chromaffin cells treated with acetylcholine (or $55 \mathrm{~mm}-\mathrm{KCl}$ ) in the presence of calcium indicated very complex temporal changes in phosphorylation sites contained in seven tryptic fragments [85]. In this study, phosphorylation of sites in three of the peptides correlates with the observed transient activation of tyrosine hydroxylase. Additional analyses suggest that these three peptides correspond to sites phosphorylated by CaM-kinase II in vitro [86]. These results strongly implicate CaM-kinase II as a physiological catalyst for phosphorylation and activation of tyrosine hydroxylase.

Liver glycogen synthase. Glycogen synthase, the rate limiting enzyme in glycogen synthesis, is subject to phosphorylation and inactivation in hepatocytes stimulated by calcium-mobilizing hormones [87]. Studies in vitro have primarily used skeletal muscle glycogen synthase, since it is more thoroughly characterized (reviewed in $[88,89])$. CaM-kinase II catalyses the phosphorylation of muscle glycogen synthase primarily at site 2, with limited phosphorylation at site $\mathrm{lb}[16,17,90]$, resulting in partial inactivation of the enzyme $[8,15,16]$. Two other calcium-dependent protein kinases can also phosphorylate glycogen synthase in vitro, namely phosphorylase kinase (site 2) $[91,92]$ and protein kinase $\mathrm{C}$ (sites la and 2) [93]. More recent results indicate that the liver isoenzyme of glycogen synthase is similar to the skeletal muscle isoenzyme in terms of its phosphorylation, except for the apparent lack of sites $1 \mathrm{a}$ and $\mathrm{lb}$ [94]. It is probable that protein kinase $\mathrm{C}$ can phosphorylate glycogen synthase in vivo, since addition of phorbol esters to hepatocytes results in the inactivation of glycogen synthase [95]. Whether CaM-kinase II is responsible for the $\mathrm{Ca}^{2+}$-dependent phosphorylation and inactivation of hepatic glycogen synthase in response to vasopressin or angiotensin II is not known.

Other substrates. Many other proteins can be phosphorylated by CaM-kinase II in vitro. In the liver, the phosphorylation state of phenylalanine hydroxylase and pyruvate kinase increases in response to calciummobilizing hormones in vivo $[87,96]$, and CaM-kinase II can phosphorylate these proteins in vitro [97-99]. However, a role for CaM-kinase II in the regulation of these proteins in vivo has not been conclusively demonstrated to date (reviewed in [46]). In heart, the activity of the $\mathrm{Ca}^{2+}$-dependent ATPase correlates with the phosphorylation state of phospholamban $[100,101]$ another substrate for CaM-kinase II [102-104], although the mechanism by which phosphorylation of phospholamban stimulates $\mathrm{Ca}^{2+}$-dependent ATPase is not known. Substrates for CaM-kinase II in tissues other than brain, liver and heart are not well characterized and many other substrates will probably be discovered.

\section{Regulation by $\mathrm{Ca}^{2+} /$ calmodulin and autophosphorylation}

Purified CaM-kinase II exhibits an absolute requirement for $\mathrm{Ca}^{2+} /$ calmodulin for initial enzyme activity. The use of chemically modified [105] and mutated [106] calmodulin has shown that the interaction between CaM-kinase II and calmodulin is considerably different than that between calmodulin and other calmodulin binding proteins. This is supported by a much higher activation constant for calmodulin for CaM-kinase II $(20-100 \mathrm{nM})[8,14,15,18,29,39]$ than with other calmodulin-binding enzymes (1-2 nM) (e.g. [107,108]). LeVine et al. $[109,110]$ studied binding of ${ }^{125}$ I-labelled calmodulin to a cytoskeletal preparation that was highly enriched in CaM-kinase II. Their results indicate a dissociation constant of approx. $7 \mathrm{nM}$, whereas the activation constant was determined to be $80 \mathrm{nM}$ in the same preparation [110]. However, the maximal stoichiometry of calmodulin 
binding to the $\alpha$ subunit of CaM-kinase II in these preparations was determined to be approx. 1:10 [109], whereas the ratio of calmodulin:kinase subunit for maximal activation of the purified, soluble kinase is approx. 1:1 (R. J. Colbran, unpublished work). More detailed studies of the interaction between calmodulin and CaM-kinase II are required to understand this process fully.

In the presence of $\mathrm{Ca}^{2+} /$ calmodulin, CaM-kinase II exhibits an intramolecular autophosphorylation reaction $[11,12,15,29,43]$ on multiple serine and threonine residues $[7,111]$, which temporally appears to preceed any phosphorylation of exogenous substrate [112]. Following $\mathrm{Ca}^{2+}$ /calmodulin-dependent autophosphorylation the regulatory properties of the kinase are significantly altered in that assays containing EGTA $\left(\mathrm{Ca}^{2+}\right.$-independent activity) now exhibit $50-80 \%$ of total kinase activity (determined in the presence of $\mathrm{Ca}^{2+} /$ calmodulin) [113-117]. This partially $\mathrm{Ca}^{2+}$-independent form of CaM-kinase II can be converted back to the completely $\mathrm{Ca}^{2+}$-dependent form by treatment with phosphoprotein phosphatase types 1 [116] or 2A [115]. Under suitable limiting autophosphorylation conditions $\left(5^{\circ} \mathrm{C}\right.$ with 5-10 $\mu \mathrm{M}$-ATP and $0.5 \mathrm{~mm}$-magnesium acetate) the generation of the partially $\mathrm{Ca}^{2+}$-independent form temporally correlates with the phosphorylation of threonine residues $[118,119]$. Analysis of $\mathrm{CNBr}$ digests of the $\left[{ }^{32} \mathrm{P}\right] \mathrm{P}_{\mathrm{i}}$-labelled rat brain kinase shows that approx. $80 \%$ of the radioactivity is in a single $3 \mathrm{kDa}$ peptide [119]. Several different criteria have been used to identify the phosphorylated residue as Thr-286 in the $\alpha$-subunit (or 287 in the $\beta$-subunit) [119]. Two other reports have recently appeared identifying Thr-286 as the major initial site of $\mathrm{Ca}^{2+} /$ calmodulin-dependent autophosphorylation in the rat brain kinase $[169,170]$.

Many earlier reports in the literature suggested various other effects of autophosphorylation on CaM-kinase II such as inactivation [43,111], increased $K_{\mathrm{d}}$ for calmodulin binding and increased $K_{\mathrm{a}}$ for calcium [109], and increased calmodulin binding and activity at low calmodulin concentrations [120]. These observations were not shown to be reversible by phosphatase treatment. Loss of kinase activity may be explained by the instability of the autophosphorylated kinase [115] and/or the use of EGTA to 'stop' autophosphorylation prior to activity assays, since the kinase undergoes additional regulatory autophosphorylation in the presence of EGTA (see below). Great care is needed in interpreting data demonstrating loss of kinase activity since the stability of the kinase is also affected by many other factors (e.g. [ATP]; unpublished work from this laboratory). As discussed above, the interaction of calmodulin with the kinase is poorly understood, and determination of any quantitative changes in calmodulin binding following autophosphorylation must await better methodology.

If CaM-kinase II is autophosphorylated in the presence of $\mathrm{Ca}^{2+} /$ calmodulin to generate the partially $\mathrm{Ca}^{2+}$ independent form, subsequent addition of excess EGTA to the autophosphorylation incubation elicits a 'burst' of additional phosphorylation for approx. $1 \mathrm{~min}[114,121]$. This $\mathrm{Ca}^{2+}$-independent autophosphorylation correlates closely with a loss of stimulation of kinase activity by $\mathrm{Ca}^{2+} /$ calmodulin [121] and the loss of ability to bind ${ }^{125}$ I-labelled calmodulin in gel overlay experiments (Fig. 2). These results are interpreted as follows: addition of EGTA chelates calcium and thereby removes calmodulin

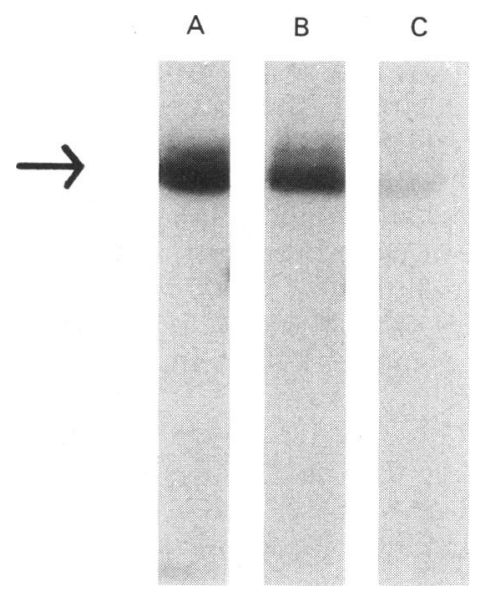

Fig. 2. Effect of autophosphorylation of CaM-kinase II on binding of ${ }^{125} \mathrm{I}$-labelled calmodulin

Rabbit liver CaM-kinase II $(190 \mu \mathrm{g} / \mathrm{ml})$ was incubated for $5 \mathrm{~min}$ at room temperature in $50 \mathrm{mM}$-Hepes containing $10 \mathrm{~mm}$-magnesium acetate, $1 \mathrm{mM}-\mathrm{CaCl}_{2}$ and $250 \mu \mathrm{g}$ of calmodulin $/ \mathrm{ml}$ in the absence (lane A) or presence (lane B) of $0.15 \mathrm{~mm}$-ATP. The incubation for lane $C$ was identical to that for lane B, except that excess EGTA (4 mM final concentration) was added after $2 \mathrm{~min}$, and the $\mathrm{Ca}^{2+}$. independent reaction was allowed to continue for an additional $3 \mathrm{~min}$. Autophosphorylation was stopped by the addition of EDTA (19 mM final concentration), and samples $(2.2 \mu \mathrm{g}$ of kinase) were prepared for electrophoresis by adding SDS sample buffer and boiling. Following SDS/polyacrylamide-gel electrophoresis, proteins were renatured, and an ${ }^{125} \mathrm{I}$-labelled calmodulin overlay was performed as described [166]. The arrow indicates the subunits of CaM-kinase II $(51 / 53 \mathrm{kDa})$ $[15,16]$.

from the kinase, exposing a new autophosphorylation site. This site is probably in close proximity to the calmodulin-binding domain and is blocked when calmodulin is bound. Addition of a negatively charged phosphate to this site prevents binding of acidic $\mathrm{Ca}^{2+} /$ calmodulin to the basic amphipathic calmodulin-binding domain. A recent abstract has identified Ser-314 and Thr-306 and/or 307 as sites of $\mathrm{Ca}^{2+}$-independent autophosphorylation [171]. Phosphorylation of the threonine residues was suggested to be responsible for the loss of calmodulin-binding ability [171].

The $\mathrm{Ca}^{2+} /$ calmodulin-dependence of CaM-kinase II can also be affected by limited proteolysis. If the kinase is first subjected to $\mathrm{Ca}^{2+} /$ calmodulin-dependent autophosphorylation to generate the partially $\mathrm{Ca}^{2+}$ independent form, partial proteolysis results in a completely $\mathrm{Ca}^{2+} /$ calmodulin-independent form [122]. Whereas $\mathrm{Ca}^{2+}$-independent autophosphorylation generates a completely $\mathrm{Ca}^{2+}$-independent kinase by loss of the ability to be activated by $\mathrm{Ca}^{2+} /$ calmodulin, partial proteolysis results in an increase in kinase activity measured in the presence of EGTA.

\section{Identification of regulatory domains in CaM-kinase II}

From the observed regulatory properties of CaMkinase II (see the previous section) and previous observations with other protein kinases, various functional domains can be postulated to occur in the 
kinase. Thus, an inhibitory domain might suppress kinase activity in the absence of $\mathrm{Ca}^{2+} /$ calmodulin. Interaction of $\mathrm{Ca}^{2+} /$ calmodulin at a calmodulin-binding domain might interfere with the inhibitory interaction and allow the expression of kinase activity. In addition, the presence of regulatory autophosphorylation sites might be predicted in close proximity to these domains since autophosphorylation has profound effects on the regulatory properties of CaM-kinase II. This section will discuss recent experiments identifying some of these regulatory domains.

Calmodulin-binding domain. Analysis of the amino acid sequence of CaM-kinase II for homologies with other calmodulin-binding proteins [31-33,44] indicates that the calmodulin-binding domain may be between residues 295 and 315 in the $\alpha$-subunit. A synthetic peptide corresponding to this region interacts with calmodulin in a $\mathrm{Ca}^{2+}$-dependent manner [31]. In order to define the boundaries of the calmodulin-binding domain more precisely, additional synthetic peptides were constructed and analysed $[123,124]$. The ability to bind calmodulin was assessed by assay of CaM-kinase II and calmodulinstimulated phosphodiesterase at limiting concentrations of calmodulin (100 nM and $2.38 \mathrm{nM}$, respectively), as well as by the ability of the peptides to alter the mobility of calmodulin in non-denaturing polyacrylamide gels in a $\mathrm{Ca}^{2+}$-dependent manner. The synthetic peptide corresponding to residues 296-309 [CaMK-(296-309); see Fig. 1] is the smallest peptide to exhibit potent calmodulin binding $[123,124]$. Extensions of the synthetic peptide at either the $N$ - or $C$-terminal [CaMK-(290-309) and CaMK-(294-319), respectively] result in no significant change in the calmodulin-antagonist potency. Thus, the major determinants for calmodulin-binding by CaM-kinase II are between residues 296 and 309 in the $\alpha$-subunit (Fig. 1). The corresponding residues in the $\beta$-subunit (297-310) are identical to the $\alpha$-subunit.

Certain structural features are thought to be important for a particular amino acid sequence to bind calmodulin. These include the ability to form an amphipathic $\alpha$-helix and clusters of basic residues with an adjacent hydrophobic region (see $[125,126]$ and references therein). Analysis of the calmodulin-binding domain of CaMkinase II indicates that the region of residues 290-309 would consist of $80 \% \alpha$-helix with clusters of basic residues (291-292 and 296-300) and a hydrophobic region (residues 301-307) [122]. Hanley et al. [124] suggest that the hydrophobic region is particularly important in the calmodulin-binding domain of CaM-kinase II since the region 296-309, which contains all of the determinants for CaM-binding, conforms poorly to the basic, amphipathic $\alpha$-helix model. Some difference between the calmodulin-binding domains of CaM-kinase II and other proteins (e.g. myosin light chain kinases; $[125,126]$ ) is to be expected since CaM-kinase II has a somewhat different interaction with calmodulin than other calmodulin-binding proteins (see previous section).

Inhibitory domain. Investigation of the functional domains of another calmodulin-regulated protein kinase, myosin light chain kinase, has shown that an inhibitory domain exists in close proximity to the calmodulinbinding domains $[127,128]$. The inhibitory domain of myosin light chain kinase acts in a pseudosubstrate manner, i.e. the inhibition is competitive with respect to the phosphate acceptor substrate [127,128]. Such pseudosubstrate-type inhibitory domains are also thought to be involved in the regulation of cAMP-kinase [129], cyclic GMP-dependent protein kinase [130] and protein kinase C [131]. Hence synthetic peptides corresponding to regions of CaM-kinase II close to and including the calmodulin-binding domain (see above) were investigated for their ability to inhibit CaM-kinase II independently of their ability to bind calmodulin. For these studies $[122,123], \mathrm{Ca}^{2+}$-independent forms of $\mathrm{CaM}$ kinase II generated by autophosphorylation or limited proteolysis (see previous section) were assayed in the presence of EGTA to preclude competition of the peptides for binding of $\mathrm{Ca}^{2+} /$ calmodulin. CaMK(296-309), the synthetic peptide which contains the major determinants for calmodulin binding, has very weak inhibitory properties $\left(\mathrm{IC}_{50} 207 \mu \mathrm{M}\right)$ [123]. Extension at the $N$-terminus to CaMK- $(290-309)$ increases the inhibitory potency $\left(\mathrm{IC}_{50} 24 \mu \mathrm{M}\right)$, and the inhibition is competitive with respect to the synthetic peptide substrate, syntide-2. However, CaMK-(290-309) is not able to inhibit the phosphorylation of intact protein substrates by CaM-kinase II [123]. Further extension to CaMK-(281-309) results in a further 10-20-fold greater potency of inhibition $\left(\mathrm{IC}_{50} 0.9 \mu \mathrm{M}\right.$ and $3.1 \mu \mathrm{M}$ for proteolysed and autophosphorylated kinase, respectively) using synthetic peptide substrate (syntide-2) and equally potent inhibition using intact protein substrate (glycogen synthase) [122]. Since approximately equal inhibitory potency is observed at $20 \mu \mathrm{M}-$ and $1 \mathrm{~mm}-$ syntide-2, it appears that inhibition by CaMK-(281-309) is noncompetitive with respect to the phosphate acceptor substrate [122]. More recent kinetic analyses indicate that this inhibition is competitive with respect to ATP (R. J. Colbran, unpublished work). Kelly et al. [132] have also synthesized the synthetic peptide CaMK(281-309) and demonstrated that it inhibits $\mathrm{Ca}^{2+}$ independent autophosphorylation of CaM-kinase II as well as phosphorylation of synapsin I. Their report indicates that the first three residues of CaMK-(281-309) are important for the inhibitory properties since $\mathrm{CaMK}$ (284-309) was a much less potent inhibitor of the kinase. However, in their study no attempt was made to determine the mechanism of inhibition. Thus, the inhibitory domain of CaM-kinase II appears to be contained within residues 281-309. More detailed studies will be required to determine the exact boundaries and crucial residues of the inhibitory domain.

Interestingly, the kinetic results reported above suggest that the inhibitory domain of CaM-kinase II does not utilize a pseudosubstrate mechanism (i.e. competitive with protein or peptide substrate), but instead blocks the ATP-binding site of the kinase. The amino acid sequence of the inhibitory domain does contain a consensus phosphorylation site (Thr-286; -R-Q-E-T-) for CaMkinase II. Thr-286 is known to be the initial site of $\mathrm{Ca}^{2+} /$ calmodulin-dependent autophosphorylation [119] and Arg-283 may be important for the inhibitory properties [132]. However, under the conditions of the kinase assay (presence of EGTA), CaMK-(281-309) is a very poor substrate for the kinase and thus the region around Thr286 cannot be interacting in a substrate-like manner. In addition, the inhibition is noncompetitive with respect to the synthetic peptide substrate ([122], R. J. Colbran, unpublished work). It should be pointed out that a shorter peptide analogue containing Thr-286 [CaMK- 
(281-289)] is a very good substrate for CaM-kinase II (see below), but is a poor inhibitor of syntide-2 phosphorylation [122]. Thus, part of the region between residues 290 and 309 is responsible for interfering with the phosphorylation of Thr-286, although this region alone does not give potent inhibition.

Inhibition of CaM-kinase II by blocking the ATPbinding site is consistent with recent investigations of the inactivation of the kinase by phenylglyoxal [133]. Phenylglyoxal selectively modifies arginine residues and shows some specificity for ATP-binding sites in proteins. CaM-kinase II is quickly inactivated by phenylglyoxal when incubated in the presence of $\mathrm{Ca}^{2+} /$ calmodulin but not in the absence of calmodulin, and inactivation is blocked by the inclusion of ADP in the incubation [133]. Thus, it appears that, in intact CaM-kinase II, access to the ATP-binding site is severely limited in the absence of $\mathrm{Ca}^{2+} /$ calmodulin, consistent with the inhibitory domain interfering with ATP-binding. These studies have recently been extended by studies using the proteolysed $\mathrm{Ca}^{2+} /$ calmodulin-independent form of CaM-kinase II that is fully active and lacks the calmodulin-binding domain and Thr-286 (M. K. Smith, unpublished work). Proteolysed kinase is rapidly inactivated by incubation with $2 \mathrm{mM}$-phenylglyoxal $(90 \%$ inactive within $15 \mathrm{~min})$, and this inactivation is blocked by the inclusion of the non-hydrolysable ATP analogue adenosine $5^{\prime}$-[ $[\beta \gamma$ methylene] triphosphate. In addition, inactivation is also blocked by CaMK-(281-309), the inhibitory domain peptide analogue which shows competitive kinetics with ATP, but not by CaMK-(290-309), which is not competitive with ATP but is partially competitive with syntide-2 (M. K. Smith, unpublished work). All of these results indicate that the inhibitory domain of CaMkinase II interacts in such a way as to interfere with the binding of ATP to the kinase. These kinetic results would be consistent with a reaction mechanism for CaM-kinase II involving binding of ATP prior to the binding of protein/peptide substrate. An ordered mechanism has been described for cAMP-kinase [134].

Autophosphorylation sites. The initial $\mathrm{Ca}^{2+} / \mathrm{calmodu}-$ lin-dependent autophosphorylation site responsible for the generation of the partially $\mathrm{Ca}^{2+}$-independent form of CaM-kinase II has recently been identified as Thr-286 ([119], see previous section). The residues around Thr-286 conform to a consensus phosphorylation sequence for CaM-kinase II (-R-Q-E-T-), and the synthetic peptide CaMK-(281-289) is a very good substrate for the kinase (apparent $K_{\mathrm{m}} 10 \mu \mathrm{M} ; V_{\max } 3.15$ $\mu \mathrm{mol} / \mathrm{min}$ per mg) [122]. However, CaMK-(281-309) is a very poor substrate for the kinase (maximal phosphorylation approx. $0.1 \mu \mathrm{mol} / \mathrm{min}$ per $\mathrm{mg}$ ) in the presence of EGTA. Presumably the inhibitory properties of CaMK-(281-309) (see above) interfere with the substrate-like interaction of the peptide. Interestingly, the phosphorylation of CaMK-(281-309) is stimulated approx. 10-fold in the presence of a molar excess of calmodulin in a $\mathrm{Ca}^{2+}$-dependent manner [122]. These results conform to the observations with the intact kinase, since in the presence of EGTA Thr-286 does not become autophosphorylated, and the addition of $\mathrm{Ca}^{2+} /$ calmodulin stimulates autophosphorylation at this residue.

CaM-kinase II must also contain a second regulatory $\mathrm{Ca}^{2+} /$ calmodulin-independent autophosphorylation site which is responsible for the loss of the ability to bind $\mathrm{Ca}^{2+} /$ calmodulin (see the previous section). The identity of this autophosphorylation site is currently under investigation. There are two consensus phosphorylation sequences for CaM-kinase II conserved in the rat brain $\alpha, \beta$ and $\beta^{\prime}$ subunits (one serine and one threonine) which can be regarded as potential autophosphorylation sites. As discussed above, the threonine is the initial site of $\mathrm{Ca}^{2+}$-dependent autophosphorylation (Thr-286 in $\alpha$ subunit). The serine (Ser-314 in $\alpha$ subunit) is in close proximity to the calmodulin-binding domain and might be a good candidate for the $\mathrm{Ca}^{2+}$-independent autophosphorylation site. A synthetic peptide, CaMK(294-319), containing this residue can be phosphorylated by CaM-kinase II, and this phosphorylation is blocked by the binding of $\mathrm{Ca}^{2+} /$ calmodulin to the peptide [135]. This behaviour is consistent with Ser-314 being a $\mathrm{Ca}^{2+}$. independent autophosphorylation site. However, there are also two additional consensus phosphorylation sequences in the $\beta$ subunit, and several other serine and threonine residues in all the subunits which may be autophosphorylated. Ser-314 has recently been identified as a site of $\mathrm{Ca}^{2+}$-independent autophosphorylation, although autophosphorylation of Thr-306 and/or -307 was suggested to result in the loss of ability to bind $\mathrm{Ca}^{2+} /$ calmodulin [171]. Neither of these threonine residues conform to the consensus phosphorylation sequence for CaM-kinase II.

Regulatory model. The results described in this section have been used to construct a 'working' model of the regulatory properties of CaM-kinase II as depicted in Fig. 3. This intramolecular model illustrates a single subunit of the oligomeric CaM-kinase II in which the inhibitory domain blocks the ATP-binding domain of the same subunit (Form 1 of Fig. 3). In support of this, the inhibitory domains of myosin light chain kinases $[127,128]$ and protein kinase $C$ [131] are thought to interact in an intrasubunit mechanism since these protein kinases are monomeric. However, a model in which the inhibitory domain of one subunit blocks ATP binding to an adjacent subunit within the same holoenzyme molecule is equally possible for CaM-kinase II. The following mechanisms would apply in either case.

Binding of $\mathrm{Ca}^{2+} /$ calmodulin to the calmodulin-binding domain (residues 296-309) induced conformational change (probably the induction of an $\alpha$-helix) which disrupts the interaction of the neighbouring inhibitory domain at the ATP-binding site, thereby activating the kinase (Form 2). This is supported by the observation that a molar excess of $\mathrm{Ca}^{2+} /$ calmodulin blocks the inhibitory action of the peptide CaMK-(281-309) [122]. Upon binding Mg-ATP, both autophosphorylation at Thr-286 and phosphorylation of exogenous substrates can occur (Form 3). Following kinase autophosphorylation, dissociation of $\mathrm{Ca}^{2+} /$ calmodulin due to a fall in $\left[\mathrm{Ca}^{2+}\right]$ does not inactivate the kinase since the presence of phosphate on Thr-286 blocks the inhibitory interaction between the inhibitory domain and the ATP-binding site (Form 4). Recent results indicate that the phosphorylated form of the synthetic peptide CaMK-(281-309) is a much less potent inhibitor of CaM-kinase II than the non-phosphorylated form $(7 \%$ and $78 \%$ inhibition, respectively, at $2 \mu \mathrm{M}$; R. J. Colbran, unpublished work). In addition, the autophosphorylated type-II regulatory subunit of cAMP-kinase has a 10-fold lower affinity for the catalytic 

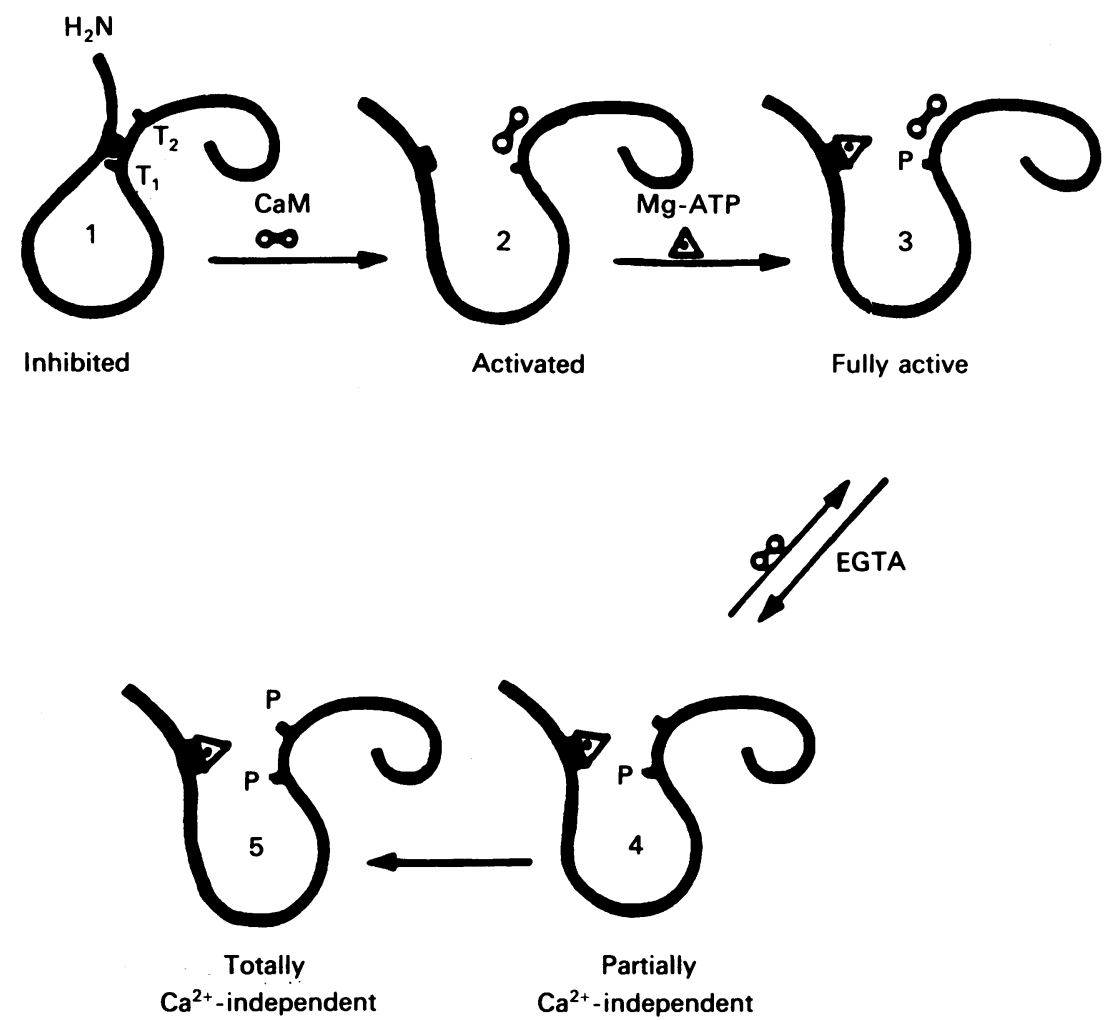

Fig. 3. 'Working' model for the regulation of CaM-kinase II

The basis for the model is detailed in the text. The symbols $T_{1}$ and $T_{2}$ refer to Thr-286 and Thr-306/307, respectively. The amino acid backbone is represented by the solid line, and the box close to the $N$-terminus represents the putative ATP-binding site around Lys-42 in the $\alpha$ subunit (see Fig. 1). Note that the model only depicts a single subunit, whereas rat brain CaM-kinase II is a dodecameric enzyme. It is equally possible to envisage that the regulatory domain of one subunit may inhibit the active site of an adjacent subunit. However, in such a model the basic features remain as depicted.

subunit $[136,137]$. Thus, in the presence of EGTA, the kinase remains partially active although it can still be activated approx. 2-fold by $\mathrm{Ca}^{2+} /$ calmodulin. According to the model, binding of $\mathrm{Ca}^{2+} /$ calmodulin blocks phosphorylation at Thr-306/307, and dissociation of calmodulin leads to the $\mathrm{Ca}^{2+}$-independent autophosphorylation at one or both of these residues (Form 5). A recent abstract suggests that $\mathrm{Ca}^{2+}$-independent autophosphorylation at these residues is responsible for the loss of ability to bind $\mathrm{Ca}^{2+} /$ calmodulin [171]. The presence of the acidic phosphate group within the basic, amphipathic calmodulin-binding domain could block further interaction with $\mathrm{Ca}^{2+} /$ calmodulin. It has been shown that the phosphorylation of a serine residue in the calmodulin-binding domain of smooth muscle myosin light chain kinase by cAMP-kinase increases the activation constant for calmodulin approx. 10-fold $[126,138]$.

The basic features of the model (Fig. 3) are supported by studies on the regulation of intact CaM-kinase II and the properties of the inhibitory domain peptide CaMK(281-309). Several aspects of this model are being further tested by site-directed mutagenesis approaches.

\section{Autophosphorylation of CaM-kinase II in vivo}

Despite extensive characterization of the autophosphorylation of CaM-kinase II in vitro, relatively little is known about autophosphorylation in intact cells or tissues. Generation of $\mathrm{Ca}^{2+}$-independent forms of $\mathrm{CaM}$ - kinase II in vivo is a particularly exciting possibility, since this would prolong the effects of a single cytosolic calcium transient, allowing phosphorylation of substrates by CaM-kinase II even when cytosolic $\left[\mathrm{Ca}^{2+}\right]$ returns to basal levels. It may seem surprising that little is known about the phosphorylation state of CaM-kinase II in vivo since it should be relatively easy to demonstrate that such covalent modification occurs. However, our own unpublished results suggest that most cells contain very potent protein phosphatases which may complicate this matter. For example, it is difficult to generate the partially $\mathrm{Ca}^{2+}$-independent form of CaM-kinase II in crude brain extracts by addition of $\mathrm{Mg}^{2+}$, ATP, $\mathrm{Ca}^{2+}$ and calmodulin. Some $\mathrm{Ca}^{2+}$-independent activity can be detected if $\mathrm{NaF}$ is added as a protein phosphatase inhibitor, but this can complicate the assay since $\mathrm{NaF}$ has been shown to inhibit CaM-kinase II [29]. Alternatively, the use of adenosine $5^{\prime}$-[ $\gamma$-thio]triphosphate in place of ATP in the above reaction allows the generation of $\mathrm{Ca}^{2+}$-independent activity since the thiophosphorylated kinase is resistant to protein phosphatases. Thus, the ratio of CaM-kinase II to protein phosphatases in each subcellular compartment is probably a crucial determinant of the extent of autophosphorylation of the kinase in vivo. It is possible that in most cells the high concentration of protein phosphatases may prevent stable autophosphorylation of CaM-kinase II, or they may rapidly dephosphorylate the kinase after homogenization. Thus, systems in which there is a high ratio of CaM-kinase II to protein 
phosphatases seem attractive candidates for investigation. In this context, the postsynaptic density is of particular interest since approx. $30-50 \%$ of postsynaptic density protein is the $\alpha$-subunit of CaM-kinase II [40-42].

The most convincing report of CaM-kinase II autophosphorylation in vivo was conducted in cultured fibroblasts (3Y1 cells). Within $20 \mathrm{~s}$ of the addition of fetal calf serum, EGF, PDGF or divalent cation ionophore (A23187 or ionomycin) there is a 3-4-fold increase in $\left[{ }^{32} \mathrm{P}\right] \mathrm{P}_{\mathrm{i}}$-labelling of serine residues in immunoprecipitated CaM-kinase II [139]. Unfortunately, the effect of these treatments on $\mathrm{Ca}^{2+}$-independent kinase activity was not reported. Since the formation of the partially $\mathrm{Ca}^{2+}$-independent form of rat brain kinase is associated with autophosphorylation of Thr-286, the regulatory consequences of the autophosphorylation of serine residues in vivo remains questionable.

Another system where changes in the phosphorylation state of CaM-kinase II have been reported in vivo is in the paradigm of kindling, an experimental model of epilepsy [140]. In these experiments [141,142], hippocampal synaptic plasma membranes, isolated from control and kindled rats, were subjected to autophosphorylation in vitro followed by analysis by SDS/polyacrylamide gel electrophoresis. It was observed that the $\alpha$ and $\beta$ subunits of CaM-kinase II incorporated less $\left[{ }^{32} \mathrm{P}\right] \mathrm{P}_{\mathrm{i}}$ in vitro after septal kindling of the rats $[141,142]$. Two alternative explanations for the decreased autophosphorylation in vitro are possible: either the activity of CaM-kinase II was decreased by kindling, or some autophosphorylation of the same sites had occurred in vivo. These alternatives were not tested.

A similar approach was adopted by Willmund et al. [143] studying visual adaptation of Drosophila to blue light. Following adaptation, an assay of $\mathrm{Ca}^{2+} /$ calmodulin-dependent protein phosphorylation in vitro in crude Drosophila head extracts revealed increased incorporation into a membrane-associated $50 \mathrm{kDa}$ protein with a time course which preceded the behavioural change [143]. In addition, blue adaptation resulted in an increased $\mathrm{Ca}^{2+}$-dependence for the $50 \mathrm{kDa}$ protein phosphorylation. On the basis of several criteria, the $50 \mathrm{kDa}$ protein was identified as CaM-kinase II [143]. The increase of $\mathrm{Ca}^{2+}$-dependent autophosphorylation in vitro could be the result of increased levels of the kinase, although this does not account for the increased $\mathrm{Ca}^{2+}$ dependence of the phosphorylation. An alternative explanation is that the increased autophosphorylation in vitro resulted from decreased autophosphorylation in vivo prior to homogenization. If the decreased autophosphorylation in vivo occured at Thr-286, it could also account for the increased $\mathrm{Ca}^{2+}$-dependence of autophosphorylation in vitro. Unfortunately, the amino acids phosphorylated were not identified.

Autophosphorylation of CaM-kinase II in vivo in the postsynaptic density has been reported in two studies $[144,145]$. Rats were injected intraventricularly with $\left[{ }^{32} \mathrm{P}\right] \mathrm{P}_{\mathrm{i}}$, and after $30 \mathrm{~min}$ the rats were decapitated and postsynaptic densities purified. In both studies the major postsynaptic density protein ( $\alpha$-subunit of CaM-kinase II) was significantly ${ }^{32} \mathrm{P}$-labelled $[144,145]$. A reservation concerning these studies is that no attempt was made to inhibit either protein kinases or protein phosphatases in the homogenates since the homogenization buffer contained $1 \mathrm{~mm}-\mathrm{MgCl}_{2}$. Thus, it is possible that the phosphorylation actually occured in the homogenate rather than in vivo. It would be of interest to repeat these studies using more controlled conditions and to determine whether the ${ }^{32} \mathrm{P}$-labelling was in threonine or serine residues.

In other studies using dispersed $\left.{ }^{32} \mathrm{P}\right] \mathrm{P}_{\mathrm{i}}$-labelled brain tissue, depolarization in the presence of external $\mathrm{Ca}^{2+}$ resulted in increased ${ }^{32} \mathrm{P}$-labelling of synapsin I $[146,147]$. However, no $\left[{ }^{32} \mathrm{P}\right]$ phosphoproteins corresponding to the subunits of CaM-kinase II were detected. These observations are consistent with a more recent study using $\left[{ }^{32} \mathrm{P}\right] \mathrm{P}_{\mathrm{i}}$-labelled synaptosomes [148]. Again, depolarization produced ${ }^{32} \mathrm{P}$-labelling of synapsin I without any apparent phosphorylation of CaM-kinase II.

Thus, whether or not CaM-kinase II undergoes stable autophosphorylation in vivo in a manner analogous to that characterized in vitro is very much an open question. However, as described above, a few reports have suggested that it may occur. The potential importance of an autophosphorylated $\mathrm{Ca}^{2+}$-independent form of CaM-kinase II in vivo is great, and more detailed characterization of the autophosphorylation of $\mathrm{CaM}$ kinase II in vivo is a particularly important avenue for future research.

An added dimension to the role of CaM-kinase II in the cell has been suggested by the recent discovery of substrates in vitro specific for the $\mathrm{Ca}^{2+}$-independent form of CaM-kinase II. Thus, calcineurin, a calmodulindependent protein phosphatase, can be phosphorylated by autophosphorylated, $\mathrm{Ca}^{2+}$-independent $\mathrm{CaM}$-kinase II, but not by non-autophosphorylated CaM-kinase II, because binding of calmodulin to calcineurin blocks the phosphorylation site [149]. Several other calmodulinbinding proteins have also been identified as substrates specific for $\mathrm{Ca}^{2+}$-independent forms of CaM-kinase II including smooth muscle myosin light chain kinase, the $63 \mathrm{kDa}$ isoenzyme of cyclic nucleotide phosphodiesterase and caldesmon (Y. Hashimoto, unpublished work).

\section{Synaptic plasticity: putative role for CaM-kinase II}

Formation of $\mathrm{Ca}^{2+}$-independent CaM-kinase II activity through autophosphorylation has been postulated to function as a molecular switch [114]. Indeed, a model has recently been proposed in which intramolecular autophosphorylation of CaM-kinase II could account for long-term storage of graded information in response to calcium influx [150]. Localization of CaM-kinase II at the postsynaptic density and its high concentration in hippocampus make it an attractive candidate for such a mechanism. It should be pointed out that all previous studies on formation of the $\mathrm{Ca}^{2+}$-independent kinase through autophosphorylation have been conducted using the purified, cytosolic form of the enzyme. However, recent studies from our laboratory have demonstrated that incubation of isolated postsynaptic density with $\mathrm{Ca}^{2+}$, calmodulin, $\mathrm{Mg}^{2+}$ and ATP converts the endogenous CaM-kinase II to a species that is $75 \% \mathrm{Ca}^{2+}$-independent (D. P. Rich, unpublished work). Furthermore, this $\mathrm{Ca}^{2+}$-independent $\mathrm{CaM}$-kinase II in the postsynaptic density is potently inhibited $\left(\mathrm{IC}_{50}\right.$ $3.6 \mu \mathrm{M})$ by the synthetic peptide CaMK-(281-309). Thus, it appears that CaM-kinase II in the postsynaptic density may be regulated in a manner similar to the cytosolic enzyme. However, the activity of the postsynaptic density kinase is approx. 10-fold lower than that of the soluble 
kinase when expressed as $\mu \mathrm{mol} / \mathrm{min}$ per $\mathrm{mg}$, even after correcting for the purity of the postsynaptic density preparation, suggesting that most of the postsynaptic density kinase is inactive. This may be because the structure of the postsynaptic density restricts access of calmodulin and/or substrates to some of the kinase molecules. In this regard, it is worth noting that LeVine et al. [109] determined that the maximum stoichiometry of calmodulin bound to a cytoskeletal preparation of CaM-kinase II was 1:10 (calmodulin: $\alpha$ subunit). Thus, some of the kinase in the postsynaptic density may serve a structural, rather than a catalytic, role, as has been suggested previously [37].

A form of synaptic plasticity that would be an attractive candidate for the involvement of CaM-kinase II is long-term potentiation. Long-term potentiation is a long-lasting increase of the postsynaptic potential following a brief, high-frequency afferent tetanization (reviewed in $[151,152]$ ). In the CA1 region of hippocampus, where long-term potentiation has been most thoroughly studied, potentiation does not develop immediately following the tetanus but, following a $3 \mathrm{~s}$ delay, reaches a maximal value after 15-20 s [152]. Furthermore, induction of long-term potentiation involves postsynaptic influx of calcium through the $\mathrm{N}$ methyl-D-aspartate receptor/ion channel $[153,154]$, a subtype of the glutamate receptor, and can be blocked by the postsynaptic injection of EGTA [155] or calmodulin antagonists [156]. Once induced, long-term potentiation can persist for several weeks in the intact rat [157]. Recent data obtained from experiments investigating the effects of protein kinase inhibitors support the hypothesis that persistent protein kinase activity is required for the maintenance of long-term potentiation [172]. The above observations on long-term potentiation, namely (1) requirement for postsynaptic calcium influx, (2) delay of onset, (3) long duration, and (4) requirement for persistent protein kinase activity, could all be explained by autophosphorylation of CaM-kinase II and formation of the $\mathrm{Ca}^{2+}$-independent form in the postsynaptic density. The $\mathrm{Ca}^{2+}$-independent form may then phosphorylate some ion channel or associated regulatory protein, thereby enhancing ion permeability in response to glutamate. For example, if the normal voltage-dependent $\mathrm{Mg}^{2+}$-blockage of the $\mathrm{N}$-methyl-D-aspartate-regulated ion channel $[158,159]$ was abolished by phosphorylation, this could result in activation of this high-conductance channel in response to glutamate release. It is well established that protein phosphorylation is an important mechanism for regulating numerous ion channels (reviewed in [160]), and several reports suggest a role for CaM-kinase II in the modulation of potassium channels [161] and calcium channels [162]. At present this model for involvement of CaM-kinase II in long-term potentiation is only a hypothesis since no supporting data has been published. The only report that may relate to long-term potentiation is the alteration of $\mathrm{CaM}$ kinase II reported in kindled rats (see above). Kindling shares many similar properties with long-term potentiation [163], including the involvement of $N$ methyl-D-aspartate receptors [164]. Experiments testing the possible involvement of CaM-kinase II in these systems are currently in progress.

We would like to thank Dr. J. D. Corbin of this department for his critical evaluation of the manuscript.

\section{References}

1. Krebs, E. G. (1985) Biochem. Soc. Trans. 13, 813-820

2. Browning, M. D., Huganir, R. \& Greengard, P. (1985) J. Neurochem. 45, 11-23

3. Nairn, A. C., Hemmings, H. C., Jr. \& Greengard, P. (1985) Annu. Rev. Biochem. 54, 931-976

4. Nairn, A. C., Bhagat, B. \& Greengard, P. (1985) Proc. Natl. Acad. Sci. U.S.A. 82, 7939-7943

5. Kennedy, M. B. \& Greengard, P. (1981) Proc. Natl. Acad. Sci. U.S.A. 78, 1293-1297

6. Yamauchi, T. \& Fujisawa, H. (1981) Biochem. Biophys. Res. Commun. 100, 807-813

7. Goldenring, J. R., Gonzalez, B., McGuire, J. S., Jr. \& DeLorenzo, R. J. (1983) J. Biol. Chem. 258, 12632-23640

8. Payne, M. E. \& Soderling, T. R. (1980) J. Biol. Chem. 255, 8054-8056

9. Erondu, N. E. \& Kennedy, M. B. (1985) J. Neurosci. 5, 3270-3277

10. Fukunaga, K., Yamamoto, H., Matsui, K., Higashi, K. \& Miyamoto, E. (1982) J. Neurochem. 39, 1607-1617

11. Bennett, M. K., Erondu, N. E. \& Kennedy, M. B. (1983) J. Biol. Chem. 258, 12735-12744

12. McGuinness, T. L., Lai, Y. \& Greengard, P. (1985) J. Biol. Chem. 260, 1696-1704

13. Yamauchi, Y. \& Fujisawa, H. (1983) Biochem. Biophys. Res. Commun. 110, 287-291

14. Kuret, J. \& Schulman, H. (1984) Biochemistry 23, 5495-5504

15. Ahmad, Z., DePaoli-Roach, A. A. \& Roach, P. J. (1982) J. Biol. Chem. 257, 8348-8355

16. Payne, M. E., Schworer, C. M. \& Soderling, T. R. (1983) J. Biol. Chem. 258, 2376-2382

17. Woodgett, J. R., Davison, M. T. \& Cohen, P. (1983) Eur. J. Biochem. 136, 481-487

18. Iwasa. T., Inoue, N., Fukunaga, K., Isobe, T., Okuyama, T. \& Miyamoto, E. (1986) Arch. Biochem. Biophys. 248, 21-29

19. Cohn, J. A., Kinder, B., Jamieson, J. D., Delahunt, N. G. \& Gorelick, F. S. (1987) Biochim. Biophys. Acta 928, 320-331

20. Bronstein, J. M., Wasterlain, C. G. \& Farber, D. (1988) J. Neurochem. 50, 1438-1446

21. Schulman, H., Kuret, J., Jefferson, A. B., Nose, P. S. \& Spitzer, K. H. (1985) Biochemistry 24, 5320-5327

22. Kinder, B. K., Delahunt, N. G., Jamieson, J. D. \& Gorelick, F. S. (1987) Endocrinology (Baltimore) 120, 170-177

23. Brooks, C. L. \& Landt, M. (1985) Arch. Biochem. Biophys. 240, 663-673

24. Rieker, J. P., Swanljung-Collins, H. \& Collins, J. H. (1987) J. Biol. Chem. 262, 15262-15268

25. DeRiemer, S. A., Kaczmarek, L. K., Lai, Y., McGuinness, T. L. \& Greengard, P. (1984) J. Neurosci. 4, 16181625

26. Palfrey, H. C., Rothlein, J. E. \& Greengard, P. (1983) J. Biol. Chem. 258, 9496-9503

27. Bass, M., Pant, H. C., Gainer, H. \& Soderling, T. R. (1987) J. Neurochem. 49, 1116-1123

28. Leonard, D. S., Wall, J. B., Pugh, P. C. \& Kennedy, M. B. (1987) Soc. Neurosci. Abstr. 13, 559

29. Schworer, C. M., McClure, R. W. \& Soderling, T. R. (1985) Arch. Biochem. Biophys. 242, 137-145

30. Shenolikar, S., Lickteig, R., Hardie, D. G., Soderling, T. R., Hanley, R. M. \& Kelly, P. T. (1986) Eur. J. Biochem. 161, 739-747

31. Hanley, R. M., Means, A. R., Ono, T., Kemp, B. E., Burgin, K. E., Burgin, K. E., Waxham, N. \& Kelly, P. T. (1987) Science 237, 293-297 
32. Lin, C. R., Kapiloff, M. S., Durgerian, S., Tatemoto, K., Russo, A. F., Hanson, P., Schulman, H. \& Rosenfeld, M. G. (1987) Proc. Natl. Acad. Sci. U.S.A. 84, 5962-5966

33. Bulleit, R. F., Bennett, M. K., Molloy, S. S., Hurley, J. B. \& Kennedy, M. B. (1988) Neuron 1, 63-72

34. Londesborough, J. \& Nuutinen, M. (1987) FEBS Lett. 219, 249-253

35. Bartelt, D. C., Fidel, S., Farber, L. H., Wolff, D. J. \& Hammell, R. L. (1988) Proc. Natl. Acad. Sci. U.S.A. 85, 3279-3283

36. Hashimoto, Y. \& Soderling, T. R. (1987) Arch. Biochem. Biophys. 252, 418-425

37. Kelly, P. T., Shields, S., Conway, K., Yip, R. \& Burgin, K. (1987) J. Neurochem. 49, 1927-1940

38. Ouimet, C. C., McGuinness, T. L. \& Greengard, P. (1984) Proc. Natl. Acad. Sci. U.S.A. 81, 5604-5608

39. Miller, S. G. \& Kennedy, M. B. (1985) J. Biol. Chem. 260, 9039-9046

40. Kennedy, M. B., Bennett, M. K. \& Erondu, N. E. (1983) Proc. Natl. Acad. Sci. U.S.A. 80, 7357-7361

41. Goldenring, J. R., McGuire, J. S., Jr. \& DeLorenzo, R. J. (1984) J. Neurochem. 42, 1077-1084

42. Kelly, P. T., McGuinness, T. L. \& Greengard, P. (1984) Proc. Natl. Acad. Sci. U.S.A. 81, 945-949

43. Kuret, J. \& Schulman, H. (1985) J. Biol. Chem. 260, 6427-6433

44. Bennett, M. K. \& Kennedy, M. B. (1987) Proc. Natl. Acad. Sci. U.S.A. 84, 1794-1798

45. LeVine, H., III \& Sahjoun, N. E. (1987) Eur. J. Biochem. 168, $481-486$

46. Soderling, T. R., Schworer, C. M., Payne, M. E., Jett, M.-F., Porter, D. K., Atkinson, J. L. \& Richtand, N. M. (1986) Colloq. INSERM 139, 141-157

47. Kemp, B. E., Graves, D. J., Benjamini, E. \& Krebs, E. G. (1977) J. Biol. Chem. 252, 4888-4894

48. Yeaman, S. J., Cohen, P., Watson, D. C. \& Dixon, G. H. (1977) Biochem. J. 162, 411-421

49. Pearson, R. B., Woodgett, J. R., Cohen, P. \& Kemp, B. E. (1985) J. Biol. Chem. 260, 14471-14476

50. DeCamilli, P., Harris, S. M., Jr., Huttner, W. B. \& Greengard, P. (1983) J. Cell. Biol. 96, 1355-1373

51. Huttner, W. B., Schiebler, W., Greengard, P. \& DeCamilli, P. (1983) J. Cell. Biol. 96, 1374-1388

52. Huttner, W. B., DeGennaro, L. J. \& Greengard, P. (1981) J. Biol. Chem. 256, 1482-1488

53. Czernik, A. J., Pang, D. T. \& Greengard, P. (1987) Proc. Natl. Acad. Sci. U.S.A. 84, 7518-7522

54. Nairn, A. C. \& Greengard, P. (1987) J. Biol. Chem. 262, 7273-7281

55. Schiebler, W., Jahn, R., Doucet, J.-P., Rothlein, J. \& Greengard, P. (1986) J. Biol. Chem. 261, 8383-8390

56. Llinas, R., McGuinness, T. L., Leonard, C. S., Sugimori, M. \& Greengard, P. (1985) Proc. Natl. Acad. Sci. U.S.A. 82, 3035-3039

57. Petrucci, T. C. \& Morrow, J. S. (1987) J. Cell. Biol. 105, 1355-1363

58. Bahler, M. \& Greengard, P. (1987) Nature (London) 326, 704-707

59. Theurkauf, W. E. \& Vallee, R. B. (1983) J. Biol. Chem. 258, 7883-7886

60. Yamauchi, T. \& Fujisawa, H. (1982) Biochem. Biophys. Res. Commun. 109, 975-981

61. Vallano, M. L., Goldenring, J. R., Buckholz, T. M., Larson, R. E. \& DeLorenzo, R. J. (1985) Proc. Natl. Acad. Sci U.S.A. 82, 3202-3206

62. Goldenring, J. R. \& DeLorenzo, R. J. (1986) Ann. N.Y. Acad. Sci. 466, 457-459

63. Yamamoto, H., Fukunaga, K., Tanaka, E. \& Miyamoto, E. (1983) J. Neurochem. 41, 1119-1125
64. Vallano, M. L., Goldenring, J. R., Lasher, R. S. \& DeLorenzo, R. J. (1986) Ann. N.Y. Acad. Sci. 466, 357-374

65. Baudier, J. \& Cole, R. D. (1987) J. Biol. Chem. 262, 17577-17583

66. Baudier, J., Mochly-Rosen, D., Newton, A., Lee, S.-H., Koshland, D. E., Jr \& Cole, R. D. (1987) Biochemistry 26, 2886-2893

67. Grundke-Iqbal, I., Iqbal, K., Tung, T.-C., Quinlan, M., Wisniewski, H. M. \& Binder, L. I. (1986) Proc. Natl. Acad. Sci. U.S.A. 83, 4913-4917

68. Ihara,Y., Nukina, N., Miura, R. \& Ogawara, M. (1986) J. Biochem. (Tokyo) 99, 1807-1810

69. Lindwall, G. \& Cole, R. D. (1984) J. Biol. Chem. 259, 5301-5305

70. Joh, T. H., Park, D. H. \& Reis, D. J. (1978) Proc. Natl. Acad. Sci. U.S.A. 75, 4744-4748

71. Yamauchi, T. \& Fujisawa, H. (1979) J. Biol. Chem. 254, 503-507

72. Vulliet, P. R., Langan, T. A. \& Weiner, N. (1980) Proc. Natl. Acad. Sci. U.S.A. 77, 92-96

73. Albert, K. A., Helmer-Matyjek, E., Nairn, A. C., Muller, T. H., Haycock, J. W., Greene, L. A., Goldstein, M. \& Greengard, P. (1984) Proc. Natl. Acad. Sci. U.S.A. 81, 7713-7717

74. Schworer, C. M. \& Soderling, T. R. (1983) Biochem. Biophys. Res. Commun. 116, 412-416

75. Vulliet, P. R., Woodgett, J. R. \& Cohen, P. (1984) J. Biol. Chem. 259, 13680-13683

76. Campbell, D. G., Hardie, D. G. \& Vulliet, P. R. (1986) J. Biol. Chem. 261, 10489-10492

77. Pigeon, D., Ferrara, P., Gros, F. \& Thibault, J. (1987) J. Biol. Chem. 262, 6155-6158

78. Richtand, N. M., Inagami, T., Misono, K. \& Kiczenski, R. (1985) J. Biol. Chem. 260, 8465-8473

79. Atkinson, J., Richtand, N., Schworer, C., Kuczenski, R. \& Soderling, T. R. (1987) J. Neurochem. 49, 1241-1249

80. Yamauchi, T., Nakata, H. \& Fujisawa, H. (1981) J. Biol. Chem. 256, 5404-5409

81. El Mestikawy, S., Glowinski, J. \& Hamon, M. (1983) Nature (London) 302, 830-832

82. Yanagihara, N., Tank, A. W. \& Weiner, N. (1984) Mol. Pharmacol. 26, 141-147

83. Pocotte, S. L., Holz, R. W. \& Ueda, T. (1986) J. Neurochem. 46, 610-622

84. Griffith, L. C. \& Schulman, H. (1988) J. Biol. Chem. 263, 9542-9549

85. Waymire, J. C., Johnston, J. P., Hummer-Lickteig, K., Lloyd, A., Vigny, A. \& Craviso, G. L. (1988) J. Biol. Chem. 263, 12439-12447

86. George, R. J., Haycock, J. W., Johnston, J. P., Craviso, G. L. \& Waymire, J. C. (1989) J. Neurochem. 52, 274-284

87. Garrison, J. C., Borland, M. K., Florio, V. A. \& Twible, D. A. (1979) J. Biol. Chem. 254, 7147-7156

88. Cohen, P., Parker, P. J. \& Woodgett, J. R. (1985) in Molecular Basis of Insulin Action (Czech, M. P., ed.), pp. 213-233, Plenum Press, New York

89. Soderling, T. R. \& Sheorain, V. S. (1985) in Molecular Basis of Insulin Action (Czech, M. P., ed.), pp. 235-245, Plenum Press, New York

90. Juhl, H., Sheorain, V. S., Schworer, C. M., Jett, M. F. \& Soderling, T. R. (1983) Arch. Biochem. Biophys. 222, 518-526

91. Soderling, T. R., Srivastava, A. K., Bass, M. A. \& Khatra, B. S. (1979) Proc. Natl. Acad. Sci. U.S.A. 76, 2536-2540

92. Embi, N., Rylatt, D. B. \& Cohen, P. (1979) Eur. J. Biochem. 100, 339-347

93. Ahmad, Z., Lee, F.-T., DePaoli-Roach, A. \& Roach, P. J. (1984) J. Biol. Chem. 259, 8743-8747 
94. Wang, Y., Camici, M., Lee, F.-T., Ahmad, Z., DePaoliRoach, A. A. \& Roach, P. J. (1986) Biochim. Biophys. Acta 888, 225-236

95. Roach, P. J. \& Goldman, M. (1983) Proc. Natl. Acad. Sci. U.S.A 80, 7170-7172

96. Garrison, J. C., Johnsen, D. E. \& Campanile, C. P. (1984) J. Biol. Chem. 259, 3283-3292

97. Doskeland, A. P., Schworer, C. M., Doskeland, S. O., Chrisman, T. D., Soderling, T. R., Corbin, J. D. \& Flatmark, T. (1984) Eur. J. Biochem. 145, 31-37

98. Schworer, C. M., El-Maghrabi, M. R., Pilkis, S. J. \& Soderling, T. R., (1985) J. Biol. Chem. 260, 13018-13022

99. Soderling, T. R., Schworer, C. M., El-Maghrabi, M. R. \& Pilkis, S. J. (1986) Biochem. Biophys. Res. Commun. 139, 1017-1023

100. Lindemann, J. P., Jones, L. R., Hathaway, D. R., Henry, B. G. \& Watanabe, A. M. (1983) J. Biol. Chem. 258, 464-471

101. Lindemann, J. P. \& Watanabe, A. M. (1985) J. Biol. Chem. 260, 4516-4525

102. Kirchberger, M. A. \& Antonetz, T. (1982) J. Biol. Chem. 257, 5685-5691

103. Simmerman, H. K. B., Collins, J. H., Theibert, J. L., Wegener, A. D. \& Jones, L. R. (1986) J. Biol. Chem. 261, 13333-13341

104. Jett, M.-F., Schworer, C. M., Bass, M. B. \& Soderling, T. R. (1987) Arch. Biochem. Biophys. 255, 354-360

105. Newton, D., Klee, C., Woodgett, J. \& Cohen, P. (1985) Biochim. Biophys. Acta 845, 533-539

106. Putkey, J. A., Draetta, G. F., Slaughter, G. R., Klee, C. B., Cohen, P., Stull, J. T. \& Means, A. R. (1986) J. Biol. Chem. 261, 9896-9903

107. Adelstein, R. S. \& Klee, C. B. (1981) J. Biol. Chem. 256, 7501-7509

108. Sharma, R. K. \& Wang, J. H. (1986) J. Biol. Chem. 261, $1322-1328$

109. LeVine, H., III, Sahyoun, N. E. \& Cuatrecasas, P. (1985) Proc. Natl. Acad. Sci. U.S.A. 82, 287-291

110. LeVine, H., III, Sahyoun, N. E. \& Cuatrecasas, P. (1986) Proc. Natl. Acad. Sci. U.S.A. 83, 2253-2257

111. Yamauchi, T. \& Fujisawa, H. (1985) Biochem. Biophys. Res. Commun. 129, 213-219

112. Kwiatkowski, A. P., Shell, D. J. \& King, M. M. (1988) J. Biol. Chem. 263, 6484-6486

113. Saitoh, T. \& Schwartz, J. H. (1985) J. Cell. Biol. 100, 835-842

114. Miller, S. G. \& Kennedy, M. B. (1986) Cell 44, 861-870

115. Lai, Y., Nairn, A. C. \& Greengard, P. (1986) Proc. Natl. Acad. Sci. U.S.A. 83, 4253-4257

116. Schworer, C. M., Colbran, R. J. \& Soderling, T. R. (1986) J. Biol. Chem. 261, 8581-8584

117. Lou, L. L., Lloyd, S. J. \& Schulman, H. (1986) Proc. Natl. Acad. Sci. U.S.A. 83, 9497-9501

118. Lai, Y., Nairn, A. C., Gorelick, F. \& Greengard, P. (1987) Proc. Natl. Acad. Sci. U.S.A. 84, 5710-5714

119. Schworer, C. M., Colbran, R. J., Keefer, J. R. \& Soderling, T. R. (1988) J. Biol. Chem. 263, 13486-13489

120. Shields, S. M., Vernon, P. J. \& Kelly, P. T. (1984) J. Neurochem. 43, 1599-1609

121. Hashimoto, Y., Schworer, C. M., Colbran, R. J. \& Soderling, T. R. (1987) J. Biol. Chem. 262, 8051-8055

122. Colbran, R. J., Fong, Y.-L., Schworer, C. M. \& Soderling, T. R. (1988) J. Biol. Chem. 263, 18145-18151

123. Payne, M. E., Fong, Y.-L., Ono, T., Colbran, R. J., Kemp, B. E., Soderling, T. R. \& Means, A. R. (1988) J. Biol. Chem. 263, 7190-7195

124. Hanley, R. M., Means, A. R., Kemp, B. E. \& Schenolikar, S. (1988) Biochem. Biophys. Res. Commun. 152, 122128
125. Blumenthal, D. K., Takio, K., Edelman, A. M., Charbonneau, H., Titani, K., Walsh, K. A. \& Krebs, E. G. (1985) Proc. Natl. Acad. Sci. U.S.A. 82, 3187-3191

126. Lukas, T. J., Burgess, W. H., Prendergast, F. G., Lau, W. \& Watterson, D. M. (1986) Biochemistry 25, 1458-1464

127. Kemp, B. E., Pearson, R. P., Guerriero, V., Jr., Bagchi, I. C. \& Means, A. R. (1987) J. Biol. Chem. 262, 2542-2548

128. Kennelly, P. J., Edelman, A. M., Blumenthal, D. K. \& Krebs, E. G. (1987) J. Biol. Chem. 262, 11958-11963

129. Corbin, J. D., Sugden, P. H., West, L., Flockhart, D. A., Lincoln, T. M. \& McCarthy, D. (1978) J. Biol. Chem. 253, 3997-4003

130. Lincoln, T. M., Flockhart, D. A. \& Corbin, J. D. (1978) J. Biol. Chem. 253, 6002-6009

131. House, C. \& Kemp, B. E. (1987) Science 238, 1726-1728

132. Kelly, P. T., Weinberger, R. P. \& Waxham, M. N. (1988) Proc. Natl. Acad. Sci. U.S.A. 85, 4991-4995

133. King, M. M. (1988) J. Biol. Chem. 263, 4754-4757

134. Whitehouse, S., Feramisco, J. R., Casnellie, J. E., Krebs, E. G. \& Walsh, D. A. (1983) J. Biol. Chem. 258, 3693-3701

135. Colbran, R. J., Fong, Y.-L. \& Soderling, T. R. (1988) FASEB J. 2, A992

136. Erlichman, J., Rosenfeld, R. \& Rosen, O. M. (1974) J. Biol. Chem. 249, 5000-5003

137. Hofman, F., Beavo, J. A., Bechtel, P. J. \& Krebs, E. G. (1975) J. Biol. Chem. 250, 7795-7801

138. Conti, M. A. \& Edelstein, R. S. (1981) J. Biol. Chem. 256, 3178-3181

139. Ohta, Y., Ohba, T., Fukunaga, K. \& Miyamoto, E. (1988) J. Biol. Chem. 263, 11540-11547

140. Wada. J. (ed.) (1982) Kindling II, Raven Press, New York

141. Wasterlain, C. G. \& Farber, D. B. (1984) Proc. Natl. Acad. Sci. U.S.A. 81, 1253-1257

142. Goldenring, J. R., Wasterlain, C. G., Oestreicher, A. B., deGraan, P. N. E., Farber, D. B., Glaser, G. \& DeLorenzo, R. J. (1986) Brain Res. 377, 47-53

143. Willmund, R., Mitschulat, H. \& Schneider, K. (1986) Proc. Natl. Acad. Sci. U.S.A. 83, 9789-9793

144. Berman, R. F., Hullihan, J. P., Kinnier, W. J. \& Wison, J. E. (1984) Neuroscience 13, 965-971

145. Gurd, J. W. \& Bissoon, N. (1985) J. Neurochem. 45, 1136-1140

146. Norling, L. L. \& Landt, M. (1986) Biochem. J. 232, 629-635

147. Dunkley, P. R., Baker, C. M. \& Robinson, P. J. (1986) J. Neurochem. 46, 1692-1703

148. Wang, J. K. T., Walaas, S. I. \& Greengard, P. (1988) J. Neurosci. 8, 281-288

149. Hashimoto, Y., King, M. M. \& Soderling, T. R. (1988) Proc. Natl. Acad. Sci. U.S.A. 85, 7001-7005

150. Lisman, J. E. \& Goldring, M. A. (1988) Proc. Natl. Acad. Sci. U.S.A. 85, 5320-5324

151. Smith, S. J. (1987) Trends Neurosci. 10, 142-144

152. Gustafsson, B. \& Wigstrom, H. (1988) Trends Neurosci. 11, 156-162

153. Collingridge, G. L., Kehl, S. J. \& McLennan, H. (1983) J. Physiol. (London) 334, 33-46

154. Harris, E. W., Ganong, A. H. \& Cotman, C. W. (1984) Brain Res. 323, 132-137

155. Lynch, G., Larson, J., Kelso, S., Barrionuevo, G. \& Schottler, F. (1983) Nature (London) 305, 719-721

156. Finn, R. C., Browning, M. \& Lynch, G. (1980) Neurosci. Lett. 19, 103-108

157. deJonge, M. \& Racine, R. J. (1985) Brain Res. 328, 181-185

158. Crunelli, V. \& Mayer, M. L. (1984) Brain Res. 311, 392-396

159. Nowak, L., Bregestovski, P., Ascher, P., Herbet, A. \& Prochiantz, A. (1984) Nature (London) 307, 462-465 
160. Kaczmarek, L. K. \& Levitan, I. B. (eds.) (1987) Neuromodulation: The Biochemical Control of Neuronal Excitability, Oxford University Press, New York

161. Sakakibara, M., Alkon, D. L., DeLorenzo, R., Goldenring, J. R., Neary, J. T. \& Heldman, E. (1986) Biophys. J. 50, 319-327

162. Hosey, M. M., Borsotto, M. \& Lazdunski, M. (1986) Proc. Natl. Acad. Sci. U.S.A. 83, 3733-3737

163. Baudry, M. (1986) Adv. Neurol. 44, 401-409

164. Mody, I. \& Heinemann, U. (1987) Nature (London) 326, 701-704

165. Hanks, S. K., Quinn, A. M. \& Hunter, T. (1988) Science 241, 42-52

166. Burgess, W. H., Watterson, D. M. \& Van Eldick, L. J. (1984) J. Cell. Biol. 99, 550-557
167. Soderling, T. R. \& Khatra, B. S. (1982) in Calcium and Cell Function (Cheung, W. Y., ed.), vol. 3, pp. 189-221, Academic Press, New York

168. Jefferson, A. B. \& Schulman, H. (1988) J. Biol. Chem. 263, 15241-15244

169. Thiel, G., Czernik, A. J., Gorelick, F., Nairn, A. C. \& Greengard, P. (1988) Proc. Natl. Acad. Sci. U.S.A. 85, 6337-6341

170. Miller, S. G., Patton, B. L. \& Kennedy, M. B. (1988) Neuron 1, in the press

171. Patton, B. L., Miller, S. G. \& Kennedy, M. B. (1988) Soc. Neurosci. Abstr. 14, 107

172. Malinow, R., Madison, D. V. \& Tsien, R. W. (1988) Nature (London) 335, 820-824 